\title{
Mercedes AGUIRRE
}

Universidad Complutense Madrid

(iD) https://orcid.org/0000-0002-8604-4826

\section{THE MYTHICAL UNDERWORLDS OF FRANCIS STEVENS AND DAPHNE DU MAURIER}

This article analyses two stories by women writers (The Heads of Cerberus by Francis Stevens (1952) and The Breakthrough by Daphne du Maurier (1964)), which could both be considered as belonging to the genre of science fiction. These stories do not follow the 'canonical' or more popular type of underworld narrative, especially the idea of the katabasis or descent to the underworld and the encounter with the dead, a motif which has often been present in Western culture since classical antiquity and has generated numerous narratives. Rather, they evoke the classical myth of the underworld through the use of certain names (such as Charon and Cerberus) as well as exploring other concepts which coincide with ancient Greek accounts of the topography and inhabitants of the world of the dead, the realm ruled over by Hades.

Keywords: Myth, underworld, science fiction, Francis Stevens, Daphne du Maurier

Słowa kluczowe: mit, podziemia, science fiction, Francis Stevens, Daphne du Maurier

\section{LOS INFRAMUNDOS MÍTOCOS DE FRANCIS STEVENS Y DAPHNE DU MAURIER}

Este artículo analiza dos historias de dos autoras (The Heads of Cerberus de Francis Stevens (1952) y The Breakthrough de Daphne du Maurier (1964)) que pueden ser consideradas pertenecientes al género de la ciencia ficción. Estas historias no siguen el tipo más popular o "canónico" de narrativa del inframundo, especialmente la idea de la katabasis o descenso al mundo subterráneo y el encuentro con los muertos, un motivo que ha estado presente a menudo en la cultura occidental desde la antigüedad clásica y ha generado numerosas narraciones. Estas historias en cambio evocan el mito clásico del inframundo a través del uso de ciertos nombres (como Caronte o Cerbero), asimismo explorando otros conceptos que coinciden con los relatos griegos sobre la topografía y los habitantes del mundo de los muertos, el reino gobernado por Hades.

Palabras clave: mito, inframundo, ciencia ficción, Francis Stevens, Daphne du Maurier 
Classical mythology offers to fantasy and science fiction many powerful representations, involving not only characters, motifs and mythical structures, but also names and visual images (Provini and Bost-Fiévet 2014: 32). Mythical names, for instance, have frequently been chosen for science fiction movies as they produce immediate recognition and help to identify new realities or unknown and mysterious situations; examples would be the Titan Prometheus in Ridley Scott's film Prometheus (2012), or Apollo in the 'Arrow of Apollo' in the series Battlestar Galactica (2003-2009). These representations appear in different forms, and their relationship with their mythical sources is not necessarily direct, as recent scholarship has demonstrated. Claire Cornillon, for instance, maintains that contemporary authors usually take inspiration from a general mythical motif rather than a particular version of a myth, and often the hypotext is difficult to identify as the mythical motif inscribes itself within a complex web of references (Cornillon 2014: 177). Again, in the view of Mélanie Bost-Fiévet and Sandra Provini (2014: 274), the use of ancient elements in the construction of an imaginary world differs according to the author's knowledge of the Greek and Latin texts - whether this is first- or second-hand, or derives from academic research or its vulgarization.

In this article I discuss one such mythical representation: the classical myth of the underworld. In Greek mythology the god Hades reigns over the land of the dead (also called Hades as the house of the god), and several Greek narratives describe the underworld, its topography and its inhabitants; Book 11 of Homer's Odyssey is the earliest example. Such descriptions and visions of the afterlife - later rewritten by Roman authors, such as Virgil in the Aeneid - became a tradition which has strongly influenced Western culture until today (Fletcher 2019).

The stories which I present here to illustrate the modern reception of the myth of the underworld were written by two $20^{\text {th }}$-century female writers, who approached a field, science fiction, which had been traditionally and predominantly masculine. Its focus on science and technology seemed 'naturally' to exclude women and considerations of gender, even though, over its history, the genre has featured a number of female authors (back to Mary Shelley's Frankenstein) (Armitt 1991: 4) and has functioned as a fertile environment for the exploration of socio-cultural understandings of gender (Merrick 2003: 241). However, although the writers of the two stories are women, the stories themselves are not women-focused, and in general issues of gender are not predominant in them. Nor could the stories be considered as 'feminist science fiction', although I shall later introduce a particular qualification of that point in relation to Francis Stevens' story. Science fiction is less central to Daphne du Maurier's work than it is to that of Francis Stevens, who, as I shall mention later, became an important figure at the dawn of the genre, whereas Daphne du Maurier's main themes concern romantic fiction, mystery and suspense. The questions which I will be addressing in relation to the two selected stories are: how the authors invoke the myth of the underworld, and whether they have similar or different practices or strategies in doing so. 


\section{Francis Stevens, The Heads of Cerberus}

Francis Stevens is the pen-name of Gertrude Mabel Barrows Bennett (18831948), who was the first major female writer of science fiction in the USA, and has been credited as the inventor of "dark fantasy" as a subgenre. She began publishing her stories under the name of 'G. M. Barrows' to disguise her gender, and finally - on the advice of her publisher - adopted the pseudonym 'Francis Stevens'. The Heads of Cerberus was written in 1919 but first published in book form in 1952 (Bleiler 1990: 704; Stableford 2003: 30).

Stevens drew sporadically on classical themes throughout her work, which suggests a degree of familiarity with them. Her 1918 short story The Labyrinth invokes Greek mythology, as does her 1920 novel Claimed, with its references to the god Poseidon and the myth of Atlantis. ${ }^{1}$ In The Heads of Cerberus, the presence of the classical underworld is already explicit in the novel's title, which refers to the adorned lid of an artistic object:

It seemed to be a glass vial. About six inches in length, it tapered to a point at one end, while the other was capped with silver, daintily carved to the shape of three dog's heads. [...] The vial was filled to the top with some substance. (p. 18).

It's old and they say 'twas made in Florence centuries ago. Said to be carved by Benvenuto Cellini for his patron, the Duke of Florence [...] (p. 19)

The Heads of Cerberus', it's called [...] the legend runs that the gray dust within it was gathered from the rocks at the gates of Purgatory by the poet Dante [...] (p. 20). ${ }^{2}$

The author is quite deliberate in using the mythological name of the canine guardian of Hades, and this already situates the reader within the classical realm of the dead: "I suppose, to represent the three-headed dog, Cerberus - the one that guarded the gates of Pluto's realm in the old mythology" (p. 19). But there is also ( $c f$. the quotation from page 20 above) an association with the Christian concept of Purgatory through the vision of Dante (who was in turn inspired by Virgil) as Cerberus in the Divine Comedy guards the third circle of Hell.

Stevens' innovative tale is often considered the first work of fantasy or science fiction to explore the concept of parallel worlds accessible via magical portals

${ }^{1}$ https://thefandomentals.com/gertrude-barrows-bennett-1/ (7/12/2020).

${ }^{2}$ It is worth recalling Agatha Christie's short story The Apples of the Hesperides, where another art object is described as having been made by Benvenuto Cellini in Florence, and is similarly associated with mysterious power and violence; both stories are related to classical mythology and the myth of the Labours of Hercules. As Christie's story is later than Stevens' The Heads of Cerberus, one may wonder whether she knew it and was inspired by it, or whether it is a simple coincidence - which might in turn suggest the existence of a tradition around Cellini's work. 
(Stableford 2003: 30), ${ }^{3}$ although James O'Neill's Land Under England (1935) already presents the same motif: after a descent through a trapdoor in Hadrian's Wall, the narrator finds himself in an eerie, silent underworld whose inhabitants communicate telepathically. ${ }^{4}$

The action of The Heads of Cerberus takes place in 1918 Philadelphia. Viola Trenmore, her brother Terence and an old friend of his and now a burglar, Robert Drayton, each successively open the vial which one of them has bought at an auction, and inhale the mysterious dust contained in it. As a consequence, they are transported to a strange limbo called Ulithia, although at first they are assumed to be dead. "And somehow, as Drayton talked, he knew that it was all true and that Trenmore was dead" (p. 30).

We do not know why the author chose the name Ulithia. Ulithi is an atoll in the Pacific which was a US Naval base during World War II, but this may be no more than coincidence. More plausibly we could think of resonances with the word 'utopia'. If we think of a Greek etymology, Ulithia could mean 'no stone' (from ou (no) and lithos (stone)). However, this makes no sense in relation to the actual place which Francis Stevens describes. A more tempting interpretation could relate to the name 'Ulysses', which in turn suggests the Homeric Odyssey and its association with journeys.

In Ulithia the travellers meet those whom they call "the Shadow People" and "The White Weaver" who, like the Greek Moirai (the Roman Parcae), or Odysseus' wife Penelope, weave in order to stop time. From there, and through the Gateway of the Moon, they end up in a futuristic version of Philadelphia in 2118, a dystopian world with a regime which uses murderous public competitions to keep the population subjugated, and in which the oppressed are identified by the large yellow buttons they are forced to wear and are only referred to by numbers. Supreme power is exercised by a woman, and once a year she oversees competitions to the death to determine who rules alongside her. ${ }^{5}$ It is worth emphasising that this idea of a female ruler in a futuristic society does not exactly represent a feminist ideology, as if it were depicting a society in which women can exercise an important role in the government; rather, the idea of such female power is presented as exceptional and dangerous, and Stevens' dystopian society is meant as a warning. In contrast with this, another story by the same author (Friend Island (1918)) depicts a society where women are admitted to be the superior sex (Merrick 2003: 244).

${ }^{3}$ In Greek mythology Hades could also be reached through caves or other special locations, for instance a cave at Tainaron where it was reported that Heracles dragged Cerberus up from Hades; the cave was known as a general place of descent for the dead (cf. Ogden, 2001: 34).

${ }^{4}$ Cf. Seed 2011: 81.

${ }^{5}$ Lucian, in his The Journey down to Hades or The Tyrant, played with the idea of the underworld as a vast city by satirically representing Hades as a bureaucracy administered by the ferryman Charon and other characters who exhibit officious concern with paperwork and accounting (Fletcher 2019: 4-5). Cities have been regularly used to embody dystopian futures (Seed 2011: 57). 
In the tradition of Gulliver's Travels and Margaret Cavendish's The Blazing World ${ }^{6}$ Viola, Terry and Robert face terrible dangers in their encounter with a totalitarian society that strikes them as bizarre and disgusting (Alderman 2019: viii). When they are forced to take part in some strange and deadly games, even condemned to be dropped into the so-called 'Pit of the Past' - where there was even a monster called The God of War-, their resourcefulness enables them to escape and return to their own world.

Although the three friends' journey into the future is not modelled on the classical katabasis into the underworld, ${ }^{7}$ it could be considered analogous to the pattern of the katabasis, and the death imagery prepares readers for a new kind of literary motif, that of the dystopian future. The theme of the voyage is indeed well known in classical myth, ${ }^{8}$ although we have no examples of the voyage into the future, only anticipations of the future in predictions: for instance, when Odysseus encounters Teiresias in Hades as one of the shades of the dead, the seer makes predictions to him about his journey back to Ithaca (Odyssey 11.90-151). Francis Stevens insists on the shadow-like existence of Ulithia and its inhabitants, who are considered "ghostly" and "phantasmal" (p. 194). Other references to Ulithia coincide with the idea of a place inhabited by ghosts: "Ulithia, phantom borderline of life" (p. 54). "Ulithia's ghostly phantasmal inhabitants" (p. 194).

The similarities between these phantoms and the shades of the dead in the Homeric Hades seem clear. ${ }^{9}$ References to "shadows" and "thin smoke" are also frequent in Stevens' story:

The people believe implicitly that should the servants become incensed and strike that Bell, the city, the people, the very earth itself would dissolve into air, like thin smoke! (p. 113).

Even when the three friends are safely back and they try to explain what has happened to them, there is a girl, Miss Skidoo, who returned with them because she had been temporarily in contact with the dust in the vial and she disappears:

${ }^{6}$ The imaginary voyage was already a narrative form which could incorporate scathing satirical fantasies (Stableford 2003: 15).

7 The Greek word katabasis means "going down" or "descent", although in Stevens, as in Homer, the journey to the land of the dead is part of a horizontal movement (Simonis 2014: 244): it is not literally a 'going down'. On the katabasis motif in science fiction films see Winkler 2001: 36-42. On the general subject of the katabasis as a literary genre in antiquity and visits to the underworld through three millennia of eastern Mediterranean history see Ekroth-Nilsson 2018.

${ }^{8}$ As Adam Roberts argues in relation to the travel motif both in science fiction and in Greek myth and literature: 'The roots of what we call Science- Fiction are found in the fantastic voyages of the Ancient Greek novel' (2015: 13). Lucian's True History, a fictional story about a journey to the Moon, can be seen as an early example of what has been described as proto-science fiction (Keen 2015: 106).

${ }^{9}$ In Book 11 of the Odyssey Odysseus refers to his encounter with his mother Anticleia in Hades: "I longed to embrace my dead mother's ghost; three times she vanished between my arms, like a fleeting shadow, a fleeting dream!" (206-207). 
In the flash of an eye the space before him was empty. Miss Skidoo had vanished more abruptly than he had himself disappeared, upon his first experience with the dust!" (p. 186) And later: "But she was nothing - a phantasm - the materialized figment of a dream (p. 195). ${ }^{10}$

In summary, by giving the name Cerberus to the vial containing the dust which acts as a magical potion to transport the characters in this story into a parallel, futuristic world, Francis Stevens already alerts the reader to look for a connection with the mythical Hades. Other features of the story do not suggest the classical underworld so explicitly, but there are certain aspects which are part of traditional patterns shared with the myth of the land of the dead.

\section{Daphne du Maurier, The Breakthrough}

Daphne du Maurier (1907-1989) had a long and varied writing career. She was interested in ambiguity and in crossing boundaries in many ways, one of them - but not the only one - in relation to gender boundaries and her own sexual identity and self-definition as a writer and a woman (Horner-Zlosnik 1998: 4-21). She was not primarily a writer of science fiction, but rather of suspense or even the Gothic (Horner-Zlosnik 1998: 21-30), as in her most famous novel Rebecca (published in 1938). ${ }^{11}$ One possible affinity with science fiction - in relation to the theme of time travel - occurs in the novel The House in the Strand, published in 1969 (Brayfield 2007: 215). But the short story The Breakthrough, ${ }^{12}$ with its secret experiments, laboratories and fanatical scientist, evokes some of the typical motifs of science fiction, and can be more seriously considered as a contribution to this genre (Hodges 2007: 38; Hietala Lilja 2020: 7, 23-2413). At the same time, the author moves once more in her usual areas of the suspense, because, as Hietala Lilja notes (2020: 24), what could create a more suspenseful effect than a possibly insane scientist with a top-secret project?

The story is narrated by Stephen Saunders, an electronics engineer who has been recruited to work at a remote location. Although the ostensible purpose is the conducting of secret military experiments, Stephen soon discovers that the scientist in charge (Mac Lean, known as Mac) is in fact attempting to extract the

${ }^{10}$ Also in Homer, in the Iliad (23.65-92), when the ghost of Patroclos appears to Achilles in a dream while he is asleep, he vanishes like smoke (for these and other examples see Aguirre 2014: 59-60).

${ }^{11}$ Most of the book by Horner-Zlosnik examines the works of Du Maurier in relation to her sexual ambiguity and to the Gothic as a literary genre.

${ }_{12}$ Written in 1964, and published for the first time in 1971 in the collection of short stories Not after Midnight and Other Stories.

${ }^{13}$ Hietala Lilja (2010: 23) notes the use of technical vocabulary, especially at the beginning of the story, which situates the reader within the genre of science fiction. On experiments in the beginnings of the science fiction genre see Stableford (2003: 18-22). 
essence of life, by developing a machine which will make it possible to trap the energy released by people when they die.

The setting is Saxmere, an isolated place on the East coast of England; such a marginal place seems appropriate for experiments relating to death and the afterlife. In the past it has been a radar station, but the present project is of an entirely different nature. When Saunders arrives at the railway station, he is met by a car to take him to his final destination. During the journey, the description of the surroundings recalls some of the topographical features of Hades:

The sandy track topped a rise and there below us, stretching into infinity, lay acre upon acre of waste land, marsh and reed, bounded on the left by sand-dunes with the open sea beyond (p. 230).

The marsh and the reeds suggest the proximity of water, which might in turn suggest the underworld rivers and the voyage across water, not only Odysseus' voyage to the land of the Cimmerians in Book 11 of the Odyssey (13-15) where he encounters the dead, but also the voyage which the souls of the dead had to take across the river Styx to reach Hades. It is worth remarking that in the 1975 film for television based on Du Maurier's story, the journey includes a ferry which crosses the water to the buildings which are the destination, suggesting unambiguously the voyage to the underworld and the crossing of the Styx. Stephen's journey then becomes a katabasis, where the first creature he meets is the guard Alsatian dog, Cerberus, a name which obviously recalls the monster who guards the gates of Hades. ${ }^{14}$ In his own journey to the underworld - as related by Virgil in book 6 of the Aeneid (418) - Aeneas also meets the monster Cerberus lying in a cave in front of him. So, the name Cerberus here, as in the previous story, gives the reader an unambiguous link with the classical world of the dead.

The driver who takes Stephen to his destination is Ken, a young boy suffering from leukaemia. Ken is a necessary element in the plot, as he will be used in the experiment at the moment of his death. Another important character is Niki, a little girl who suffers from some sort of mental disability. A vulnerable child, the only survivor of identical twins, she will be used in connection with what the experimenters call Force Six:

He believes that when he puts out the call it connects Niki with what he calls Force Six, which in her case is doubled because of the dead twin. [...] Do you mean, I asked, that when the call goes through the dead twin somehow takes over? [...] Good Lord, no! There's nothing left of poor Penny but electric energy, still attached to her living twin. That's why Niki makes such a useful guinea-pig. (p. 249).

On the one hand we have the idea of the twin girls, and the concept that the dead girl passes her supernatural force to her surviving sister; on the other hand, there is the notion of the force or vital energy as the double of the self. The idea

\footnotetext{
14 See note 7.
} 
of the shadow or the double also appears in other works by du Maurier (such as the novel The Scapegoat (1957) and the short story Don't Look Now (1971)). The double is also, of course, a significant motif in science fiction: one thinks of the classic film Invasion of the Body Snatchers (1956), or the replicants in the 1982 film Blade Runner and its 2017 sequel Blade Runner 2049..$^{15}$

There is one more name in du Maurier's story related to the classical Hades: Charon. " ... a computer capable of speech, though its vocabulary was limited and the actual 'voice' was far from perfect [...] I call it Charon 1. (p. 237).

$\mathrm{Du}$ Maurier adds an explanation which confirms her intentional and conscious use of references to the Greek underworld: "Charon, if I remember rightly, was the ferryman who conveyed the spirits of the dead across the Styx". (p. 237).

There are even other computers, called Charon 2 and Charon 3, which are meant to work together in the final experiment: "We are geared and ready for the great experiment, when Charons 1 and 3 will be used in conjunction..." (p. 242).

And that will be called 'Operation Styx', with another name deriving from the classical underworld: "Phase two of Operation Styx consisted of bringing the operating table in here, placing it between the three Charons, and connecting up with an oxygen unit alongside" (p. 255).

The computers can in turn capture and manipulate the 'vital spark' - in other words, the soul. The experiment will push the boundaries of technology and, as the scientist affirms: "if we succeed, $[\ldots]$ we shall have the answer at last to the intolerable futility of death." (p. 243).

Once again Du Maurier alludes to the Greeks, in this case comparing the scientific experiment with ancient myth and belief: "The energy is there, you know, when it leaves the body on the point of death. [...] all that energy escaping as we die $[\ldots]$ the Greeks believed in it [...]." (p. 241)

The text indeed refers to the psyche -the soul or breath which the Greeks thought flew from the body at the moment of death, ${ }^{16}$ and was thus often represented in vase-painting as a small human figure with wings, which could sometimes also represent the souls of the dead on their way to Hades (Aguirre 2014: 57-58).

As Ken lies at the point of death, he is put under hypnosis along with Niki. The idea of putting a person in a suspended hypnotic trance at the moment of death reminds us of Edgar Allan Poe's famous short story The Facts in the Case of M. Valdemar (published in 1845), which might indeed have inspired Du Maurier. Initially it seems the experiment has been a success, with the computers showing that Ken's energy has been captured. But after the point of Ken's death Niki, still under hypnosis, reports that Ken is asking the experimenters to let him go, and

15 The motif of the double or Doppelgänger is a common theme in horror literature as well as science fiction (Kogel-Schaefer 2011).

${ }^{16}$ On the theme of the psyche see, among others, Bremmer (1983). 
they realise that they may have captured more of Ken than his psychic energy. Horrified, they disconnect the apparatus and release the energy.

$\mathrm{Du}$ Maurier's story hedges its bets between the supernatural and science fiction. In the end, it does not give the impression of providing a definitive solution to the complicated and imaginative plot; or, at least, it is a disappointing solution, even if in a way it expresses the success of the experiment. In the process of constructing her idea of the classical underworld, Du Maurier is more intensely involved than Francis Stevens. Du Maurier was always fascinated by questions of life and death: apparently she herself believed in an afterlife, and, although she did not pretend to have any idea what it consisted of, she often posed the question about it (Hodges 2002: 38). It is clear that, as she had a strong knowledge of classical myths, ${ }^{17}$ in this story she tries to convey the idea of death and the afterlife through the motifs and names of the classical underworld. ${ }^{18}$ The story reveals its relationship with classical antiquity above all through the presence of proper names from myth, which help to assure a continuity between the characters of the story and the reader through the assumption of a shared cultural background, in this case in connection to the world of the dead. ${ }^{19}$

In the two stories that I have discussed above, Stevens and Du Maurier explore two well-established thematics of science fiction: the voyage into the future and the scientific experiment. In so doing, they engage repeatedly with the myths of classical antiquity; and they do so in different ways. Neither story refers explicitly to a journey to the underworld, nor are they adaptations of any specific ancient literary version of the descent to the underworld. But they do incorporate concepts, motifs and names which are rooted in the Classical tradition, and which help to elaborate an imaginary world in which the reader can listen to insistent resonances of the mythology of the Greco-Roman world of the dead.

\section{Bibliography}

Aguirre, M. (2014). Caracterización y representación de los fantasmas en la antigua Grecia in Fantasmas, aparecidos y muertos sin descanso. In: M. Aguirre, C. Delgado, A. González-Rivas (ed.). Madrid: Abada. 55-65.

Alderman, N. (2019). "Introduction" to Francis Stevens, The Heads of Cerberus. New York: Modern Library. https://doi.org/10.1515/9781618110558-001

${ }^{17}$ As was confirmed personally to the author of this article by Du Maurier's son Kits Browning: "My mother was extremely well read and quite an expert on classical mythology" (19 ${ }^{\text {th }}$ August 2014).

${ }^{18}$ Heeley (2007: 124-132) remarks that Du Maurier expressed her thoughts and feelings on both Christianity and paganism, rebelling against traditional Christian religion, respecting tradition and celebrating pagan aspects of Earth as mother goddess and the power of chthonic forces.

${ }_{19}$ Although Du Maurier used classical myths in other works (especially short stories such as Ganymede and Not until Midnight) it is interesting that she has chosen to use it here in particular, in a subject related to death, as if she were giving a transcendent importance to this theme. 
Armitt, L. (ed.). (1991). Where no man has gone before: Women and science fiction. London-New York: Routledge.

Bleiler, E.F. (1990). Science Fiction. The Early Years. Kent, Ohio: Kent State University Press.

Bost-Fiévet, M., Provini, S. (2014). Sur des pensers anciens faisons des mondes nouveaux. In: M. Bost-Fiévet, S. Provini (ed.). L'Antiquité dans l'imaginaire contemporain. Fantasy, science-fiction, fantastique. Paris: Classiques Garnier. 273-283.

Brayfield, C. (2007). The House of the Strand. In: The Daphne du Maurier Companion. London: Virago Press. 210-216.

Bremmer, J. (1983). The Early Greek Concept of the Soul. Princeton: Princeton University Press. https://doi.org/10.1515/9780691219356

Cornillon, C. (2014). Moi, Thésée, je decouvrirai les chemins de l'espace. In: M. Bost-Fiévet, S. Provini (eds.). L'Antiquité dans l'imaginaire contemporain. Fantasy, science-fiction, fantastique. Paris: Classiques Garnier. 175-186.

Du Maurier, D. (2006). The Breakthrough in Don't Look Now and Other Stories, London: Penguin.

Ekroth, G., Nilsson, I. (eds.). (2018). Round Trip to Hades in the Eastern Mediterranean Tradition: Visits to the Underworld from Antiquity to Byzantium. Leiden: Brill. https://doi.org/10.1163/9789004375963

Fletcher, J. (2019). Myths of the Underworld in Contemporary Culture. Oxford: Oxford University Press. https://doi.org/10.1093/oso/9780198767091.001.0001

Hall, E. (2012). The Return of Ulysses, London: I.B.Tauris.

Heeley, M. (2007). Christianity versus Paganism: Daphne du Maurier's Divided Mind. In: H. Taylor (ed.). The Daphne du Maurier Companion. London: Virago Press. 122-132.

Hietala Lilja, J. (2020). Anticipation, Uncertainty and Concern for Characters: Suspense in Daphne du Maurier's Short-Story Collection Don 't Look Now. MA Thesis, Helsinki: Helsingin yliopisto.

Hodges, S. (2007). Editing Daphne du Maurier. In: H. Taylor (ed.). The Daphne du Maurier Companion. London: Virago Press. 25-43.

Horner, A., Zlosnik, S. (1998). Daphne du Maurier. Writing, Identity and the Gothic Imagination. London: McMillan Press. https://doi.org/10.1057/9780230378773

Keen, A. (2015). Mr. Lucian in Suburbia: Links Between the True History and The First Man in the Moon. In: B.M. Rogers, B.E. Stevens (eds.). Classical Traditions in Science Fiction. Oxford: Oxford University Press. 105-120.

Kogel, D., Schaefer, I. (2011). The Doppelgänger motif in Science-Fiction film. In: S. Georgi, K. Loock (eds.). Of Body Snatchers and Cyberpunks: Student Essays on American Science-Fiction. Göttingen: Universität Göttingen. 125-141. https://doi.org/10.17875/gup2021-1678

Merrick, H. (2003). Gender in Science Fiction. In: E. James, S. Mendelsohn (eds.). The Cambridge Companion to Science Fiction. Cambridge: Cambridge University Press. 241-252. https://doi. org/10.1017/CCOL0521816262.019

Ogden, D. (2001). Greek and Roman Necromancy. Princeton: Princeton University Press. https:// doi.org/10.1515/9780691207063

Provini, S., Bost-Fiévet, M. (2014). L'antiquité gréco-latine dans l'imaginaire contemporain, Introduction générale. In: M. Bost-Fiévet, S. Provini (eds.). L'Antiquité dans l'imaginaire contemporain. Fantasy, science-fiction, fantastique. Paris: Classiques Garnier. 15-34.

Roberts, A. (2006). The History of Science Fiction. Basingstoke: Palgrave Mcmillan. https://doi. org $/ 10.1057 / 9780230554658$

Rogers, B.M., Stevens, B.E. (2015). Classical Traditions in Science Fiction. Oxford: Oxford University Press.

Seed, D. (2011). Science Fiction. A Very Short Introduction. Oxford: Oxford University Press. https://doi.org/10.1093/actrade/9780199557455.001.0001

Simonis, A. (2014). Voyages Mythiques et passages aux enfers. In: M. Bost-Fiévet, S. Provini (eds.). L'Antiquité dans l'imaginaire contemporain. Fantasy, science-fiction, fantastique. Paris: Classiques Garnier. 241-252. 
Stableford, B. (2003). Science Fiction before the genre. In: E. James, S. Mendelsohn (eds.). The Cambridge Companion to Science Fiction. Cambridge: Cambridge University Press. 15-31. https://doi.org/10.1017/CCOL0521816262.002

Stevens, F. (2019). The Heads of Cerberus. New York: The Modern Library.

Dr Mercedes Aguirre - Doctor in Classical Philology (Universidad Complutense, Madrid). Honorary Research Fellow, University of Bristol. Profesor Honorífico, Universidad Complutense, Madrid. For many years she lectured on Greek Philology at the Universidad Complutense in Madrid. She has published on Greek literature, mythology, iconography, and the reception of Greek mythology in the contemporary world. Among her scholarly articles are those on: Scylla, the Gorgons, ghosts, female characters in the Odyssey and studies of particular myths and their reception in modern and contemporary art. With Richard Buxton she has co-authored Cyclops: The Myth and its Cultural History (Oxford University Press, 2020). She is also the author of several books of fiction, some of them inspired by Greek mythology.

e-mail:macics@yahoo.co.uk 